\title{
Beyond QCD-S Practices in Automotive Industry: A Review of Contemporary QCD-S Paradigms
}

\author{
Mohd Akhir Hj Ahmad, Rushami ZienYusoff \\ University Utara Malaysia, Malaysia \\ makhir@uum.edu.my
}

\begin{abstract}
The application of Quality, Cost and Delivery (QCD) practices in science management has made a significant impact both in industrial and academia for over the last decade. Fostered by rapid development in the automotive industry including environment, economic and social issues, there has been a significant development of QCD-S (Sustainability) in PDCA (Plan-Do- Check-Action) and Lean Manufacturing (LM). This paper will attempt to investigate the beyond QCD practices in the automotive industry. A linkage of the QCD-S paradigms with included sustainability product development is the new path of the current philosophy.
\end{abstract}

Keywords: Quality Cost and Delivery, Automotive industry, Sustainability

\section{Introduction}

The fundamental of QCD (Quality-Cost-Delivery) had been changed the practices among the manufacturing as their based on practising the lean manufacturing, JIT approach, 5's practices toward customer satisfaction and organizational performance. However, new concepts of practices are known QCD-S (Quality-CostDelivery-Sustainability) have replaced this paradigm in more toward in broad issues of focusing customer focus. It considers the development of a product with consists of environment, economic and social elements. Lagrosen (2000) argued that the organization should focus far beyond customer satisfaction. Moreover, in this context, the scope of beyond customer focus shall be included the environment, economic and social issues during new product development of automotive parts. Specifically, automotive sector has provided a good economy to each developing country. However, the process of their product and manufacturing has significant impact to the environment and social issues (Nunes \& Bennet, 2010). In this study, the research is attempting to look beyond the current concepts of QCD practices and prefer the integration of QCD with sustainable product development will create new paradigms of QCD-S practices in the automotive industry.

Current Issues of QCD: Quality, Cost and Delivery (QCD) metrics are nothing new in the manufacturing sector especially in the automotive industry. It is used in the manufacturing sector as an important element of the lean improvement toolkit. QCD also is used in developing business measures as key performance indices (KPI's). In this context, quality is referring to the quality of products that meets or exceeds customer satisfaction. The cost is involving the each step in the manufacturing process, while delivery is organized schedule to meet internal and external customer requirement.

Quality: According to Imai (1986) QCD definition is mainly divided into three main scopes. The first scope is term of quality it refers finished products, process and services. The second scope is cost of design, production, and selling. The third scope is delivery it means delivering the requested volume on time. In other context, QCD also used as indicators to measure key performance indicators (KPI) of the organization. Crosby (1989, p. 50) emphasized that achieving the quality of products in the organization have several concepts are needed to be understood and implement in whole of the organization. Further, he claimed that the quality has conformed to the requirements. In other words, the main objective of implementing the quality practices in the organization is preventing the errors or failures within a process or activity and reduces the cost of reworks and achieved customer satisfaction.

Cost: The cost definition of QCD concept is referring to cost management (Imai, 1986). The cost management is overseeing the process of developing, producing, and selling the products to the customer. The spectrum of cost management it including cost of planning that involves the product from the design stage until sales to the market. Furthermore, (Imai, 1986) stressed that several issues of cost management in the manufacturing context, such as quality improvement, reduce costs and improve delivery time. 
Delivery: Delivery the products within a specified time frame will give more advantages to those organizations without proper plan to meet customer needs and target. Imai (1986) claimed that delivery concept it refers to timely delivery with a specific volume of products. It concerns on how JIT (Just in Time) is proper tools in concept of delivery in production scope.

\section{Future Issues of QCD-S Practices}

In recent years, sustainable product development has evolved into consideration based on the use of triple bottom line which known as economic, environmental, and social (Hemming et al., 2004). On other view, Reinhardt (2000) has approached that company for an integration of sustainable development into the overall position of the product into their business strategy. Whereby, Van der Hoek (2002) emphasized that other important issue is needed to consider of customers that are willing to pay for a green product. The concept of sustainable development was introduced in the 1970s, it concern of global pollution and increasing raw material (De Ron, 1998). Berry and Rondinelli (1998) mentioned that rapid changes in corporate environment in the late 1990s may validate predictions of environmental consciousness among business leaders in the new industrial revolution in the twenty first century. Moreover, Hart (1997) claimed that environment should be protected and it should give concern on effectively manage environmental issues in the organization (Berry \&Rondinelli, 1998). Nowadays there increasing requirement of environmental friendly products (Anbumozhi \& Kanda, 2005). It was supported by Banerjee (2001) claimed that environmental problem today have expanded from local and regional to global stage. In expanding the understanding of the global issues the term triple bottom line has been used as a paradigm to appraise the success of an organization. The author believes that the paradigms of QCD-S is major issues are needed to be raised in new product development of automotive products. Figure 1 recommended the framework of QCD-S paradigm of developing new products in the automotive industry.

Figure 1: A cause and effect diagram of QCD-S practices (Source: Adapted from Imai (1986) p.111)

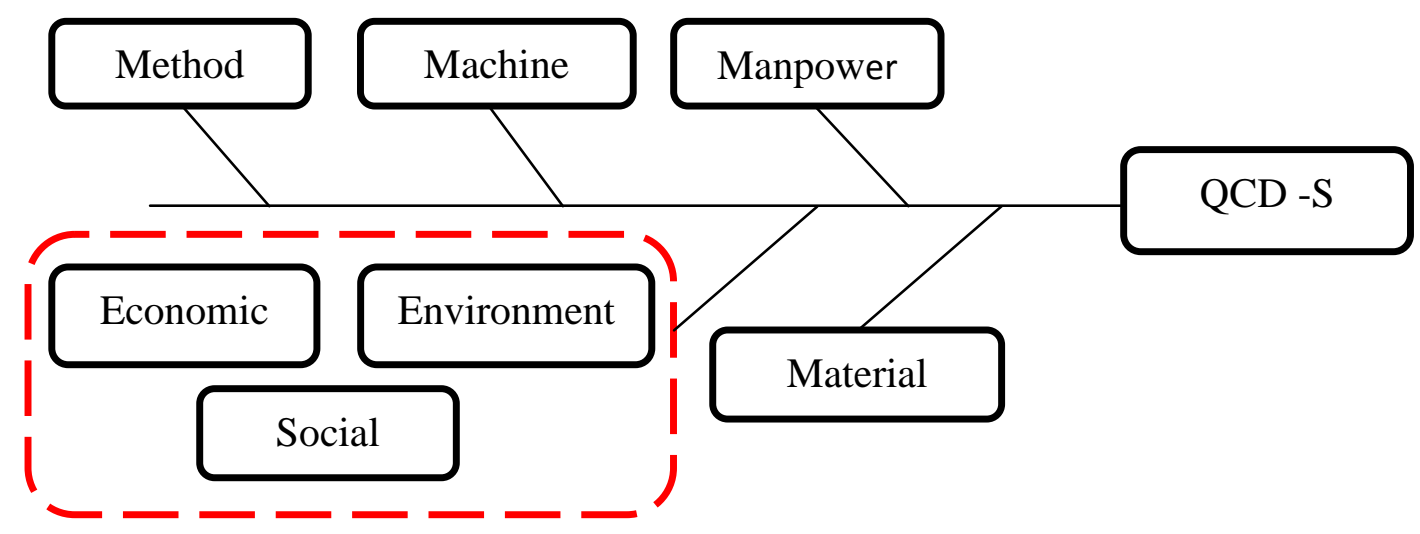

Figure 1 shows a cause and effect diagram of QCD-S practices. These diagrams are adapted from Ishikawa fish bone that to be included with sustainability of products that consist of environment, economic and social elements.

\section{Conclusion}

There is an increasing trend of environmental and social responsibility in business (Axelrod, 2000). Thus, it needs to be mixed with the quality management on this evolution (Allen et al., 2000). The topic of social effect on quality has been discussed by previous scholars such as Deming (1986). Ishikawa (1985) also claimed that there are need interaction between society and industry. In such reason, the framework of this study recommended that the economic, environment and social are important elements in new product development in the automotive sector. In other word, the QCD practices have been changed to next paradigms of QCD-S practices in the manufacturing industry, especially in the automotive sector. 


\section{References}

Allen, C., Sommerville, L., Kennedy, P. \& Robertson, H. (2000). Driving for business excellence through environmental performance. Journal of Total Quality Management, 11(4), 602-607.

Anbumozhi, V. \& Kanda, Y. (2005). Greening the production and supply chains in Asia: Is there a role for voluntary initiatives? Institute for Global Environmental Strategies (IGES). Hyogo: Kansai Research Centre, JAPAN.

Axelrod, R. (2000). The financial value of commercial communications. Environmental Quality Management, 9(4), 1-11.

Banerjee, S. B. (2001). Corporate citizenship and indigenous stakeholders: Exploring a new dynamic of organisational-stakeholder relationships. The Journal of Corporate Citizenship, 1(1), 39-55.

Berry, M. A. \& Rondinelli, D. A. (1998). Proactive environmental management: A new industrial revolution. The Academy of Management Executive, 12(2), 38-50.

Crosby, P. B. (1989). Let's Talk Quality: New York: McGraw Hill.

De Ron, A. J. (1998). Sustainable production: The ultimate result of a continuous improvement. International Journal of Production Economics, 56-57, 99-110.

Deming, W. E. (1986). Out of the Crisis. Cambridge: Cambridge University Press.

Hart, S. L. (1997). Beyond greening: Strategies for a sustainable world. Harvard Business Review, 75(1), 67-76.

Hemming, C., Pugh, S., Williams, G. \& Clackburn, D. (2004). Strategies for sustainable development: Use of a benchmarking tools to understand relative strength and weakness and identify best practice. Corporate Social Responsibility and Environmental Management, 11(2), 103-113.

Imai, M. (1986). Kaizen: The Key to Japan's Competitive Success. New York: Random House.

Ishikawa, K. (1985). What is Total Quality Control? - The Japanese way. New York, Englewood Cliffs: PrenticeHall.

Lagrosen, S. (2000). Born with quality: TQM in a maternity clinic. The International Journal of Public Sector Management, 13(5), 348-354.

Nunes, B. \& Bennet, D. (2010). Green operations initiatives in the automotive industry. Benchmarking: An International Journal, 17(3), 396-420.

Reinhardt, F. L. (2000). Down to Earth. Boston, MA: Harvard Business School Press.

Van Der Hoek, K. W. (2002). Uitgangspuntenvoor de mest-en ammoniaberekeningen 1997 tot en met 1999 zoalsgebruikt in de Milleubalans 1999 en 2000. The Netherland: RIVM Rapport 773004012, RIVM, Bilthoven. 